\title{
HOURLY DISTANCES AND ALTITUDES OF A RECENTLY-FLEDGED TURKEY VULTURE ON ITS FIRST SOUTHBOUND MIGRATION *
}

C. STUART HOUSTON, 863 University Drive, Saskatoon, SK, S7N 0J8, E-mail: <stuart.houston@usask.ca>; DAVID R. BARBER, Hawk Mountain Sanctuary, Kempton, PA, 19529; BRENTON TERRY, 64 MacLean Crescent, Saskatoon, SK, S7J 3R7; MARTEN J. STOFFEL, Box 183, RR\#4, Saskatoon, SK, S7K 3J7; MICHAEL BLOM, 875 Wedgewood Court, Peterborough, ON, K9J 7T8; JAMES MANDEL, Cornell University, Ithaca, NY, 14850 and KEITH L. BILDSTEIN, Hawk Mountain Sanctuary, Kempton, PA, 19529.

* Hawk Mountain Contribution to Conservation Science, Number 172

\section{Introduction}

In 2004, we fitted a nestling Turkey Vulture with a satellite transmitter, and subsequently documented its first fall migration from Saskatchewan to Costa Rica and its return the following spring as far as Nebraska. ${ }^{5}$ In 2007 , we fitted another nestling at the same nest with a transmitter that yielded more accurate and frequent locations, and followed its migration southward. Here we report on the results of this recent migration, compare it with the previously monitored one, and provide estimates of migration speed and elevation.

\section{Methods}

On August 5 2004, a Turkey Vulture nestling was fitted with a $35 \mathrm{~g}$ solarassisted satellite platform terminal transmitter (PTT) and patagial tag $\mathrm{H} 25$. The nest was in a long-deserted farm house west of Ranger, SK (53.6249 $\mathrm{N}, 107.7620 \mathrm{~W}$ ), where Ken McDaid, the neighboring farmer, had observed a nesting vulture each summer since 2002. The PTT averaged five irregular Doppler transmissions per day, with accuracy varying between $150 \mathrm{~m}$ and
$10 \mathrm{~km} .{ }^{1}$ The four highest accuracy ratings provided 346 locations during its 67-day migration to its wintering grounds in the mountains south of San Jose, Costa Rica. ${ }^{5}$

On August 5, 2007, a second Turkey Vulture nestling from the same nest site west of Ranger was fitted with an improved PTT that was capable of hourly reporting with a global positioning system (GPS). The $70 \mathrm{~g}$ solar-powered PTT-100 transmitter \#65543 (manufactured and refurbished by Microwave Telemetry, Inc., Columbia, Maryland) ${ }^{8}$ was attached to the bird's back and contained sensors for temperature, battery voltage, transmission counts and activity counts. The PTT transmitted hourly at a frequency of $401.650 \mathrm{MHz} \pm 36 \mathrm{kHz}$, giving spatial readings within $\pm 15 \mathrm{~m}$ and altitude readings accurate to $\pm 22 \mathrm{~m}$. A patagial tag, number $\mathrm{A} 33$, was placed on the right wing at the same time and here we refer to this individual Turkey Vulture by this tag number. Techniques for application of the backpack transmitter and the approval of the Animal Care Committee, University of Saskatchewan, were as described previously. ${ }^{5}$ 


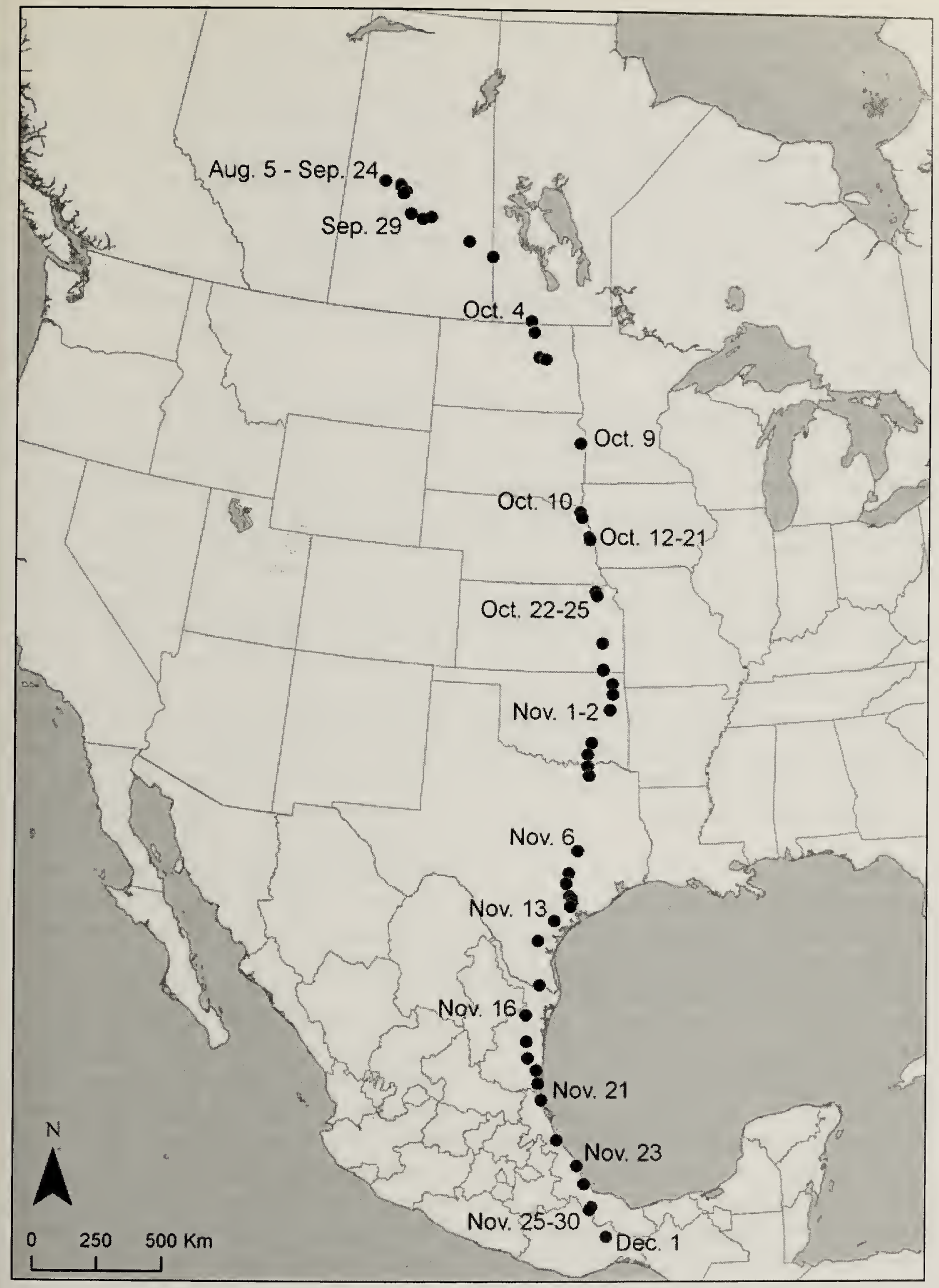

Figure 1. Each dot represents the bird's position at the beginning of a "travel day". Map by David R. Barber 
Hourly distances and daily total distances were calculated using Grinwich. Days with all hourly distances less than $5.4 \mathrm{~km}$, assumed to be consistent with feeding movements rather than migration, are referred to here as 'rest days'; those with at least one hourly distance greater than $5.4 \mathrm{~km}$ are called 'travel days'. Distances are rounded to the nearest $\mathrm{km}$ and time is given in Central Standard Time (CST).

To get a rough estimate of how high above the ground A33 was flying, we took the altitude of the night-time roost to represent the average ground level of the terrain it was flying over during the day. Each flight altitude was the number of meters above the night-time roost. Using the night-time roost to approximate ground level for the previous day's travel seemed justified because A33 traveled across the relatively flat terrain of the Great Plains in Canada and the United States, and along the coast in Mexico.

\section{Results}

Transmitter readings indicated that the vulture first moved out of the farm house at 1000 h on August 13; it roosted outside the house that night and for the 10 subsequent nights. Morning flights of 130, 150, 270 and then 330 meters began on August 14 . On August 28, the vulture was back beside the house. A flight of $610 \mathrm{~m}$ was made in the evening of September 4. Its first flight of more than $1 \mathrm{~km}$ occurred on September 10, and the first over $2 \mathrm{~km}$ on September 19, the day that Ken McDaid phoned to tell $\mathrm{CSH}$ he saw the tagged nestling flying at a distance from the house. On each of these flights and many shorter ones, the bird returned promptly to near where it began.

At $1000 \mathrm{~h}$ CST on September 24, 2007 , the bird traveled $19 \mathrm{~km}$ south in
3 hours but returned to its nest site 2 hours later. The next day its southbound migration began at $1100 \mathrm{~h}$. It traveled or rested for 69 days in a gentle arc through Manitoba, North Dakota, South Dakota, Nebraska, Kansas, Oklahoma and Texas, and along the gulf through Tamaulipas and most of Vera Cruz. It then veered inland to Oaxaca, Mexico on November 30 and December 1 (Figure 1).

Location data for A33 were received every hour for all 24 hours on 45 of the 69 days (Tables $1 \mathrm{a}-1 \mathrm{~d}$ ). In all, 1565 signals $(94.5 \%)$ were received from a potential total of 1656 hours, as the vulture traveled $5014 \mathrm{~km}$ in 69 days. The number of hours of data received on the remaining 24 days ranged from 16 to 23. Three travel days, two of them in important locations, one at the Nebraska-Kansas boundary and the other during the final day in Oaxaca when the vulture presumably died, had an inadequate number of signals to determine hourly distances ( 7 signals on October 7, 16 on November 19, and 11 on the final day, December 1 , each marked by "?" in Table 1). Only the total daily distance was known for those three days.

We designated 49 of the 69 days as travel days, i.e. days in which the vulture traveled more than $5.4 \mathrm{~km}$ in one hour. On 2 travel days A33 flew 1 hour, on 6 days it flew 2 hours, and on 4, 8, 9, 6, 8 and 2 days it flew for $3,4,5,6,7$ and 8 hours, respectively. On seven of these travel days, interruptions midway during that day's travel occurred for one $(n=5)$ or two $(n=2)$ hours. On average, A33 flew 4.3 hours during each travel day, or just over 3 hours per 24 hour period for the 69 days elapsed time, including the 20 rest days.

On five days (October 4, 9, 10 and 21 , and November 6 ), the vulture traveled more than $200 \mathrm{~km}$. Only five 


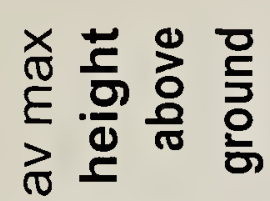

ষ

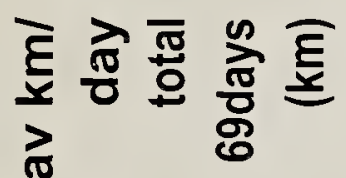

冓

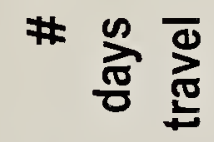

a)

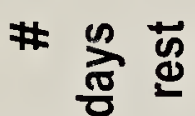

N

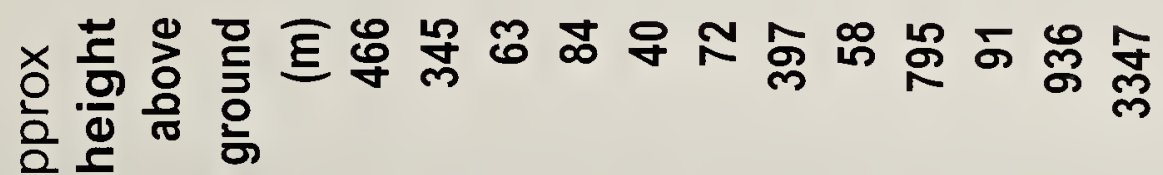

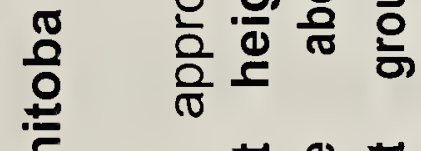

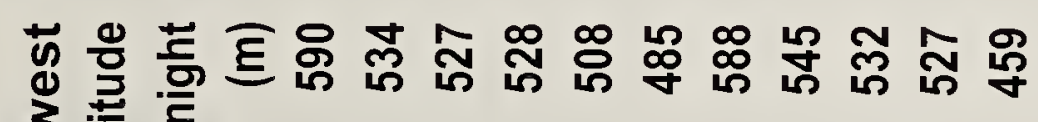

으 춘

$+$

5
$\frac{5}{3}$
3
$\frac{1}{0}$
$\frac{\pi}{0}$
$\frac{x}{0}$
0
0
0

N

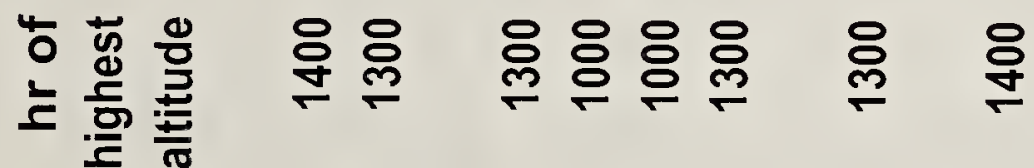

药至

을

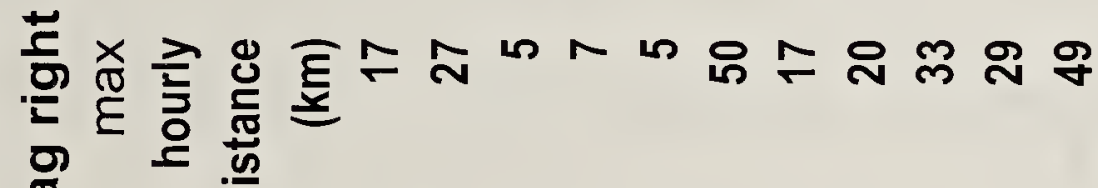

向

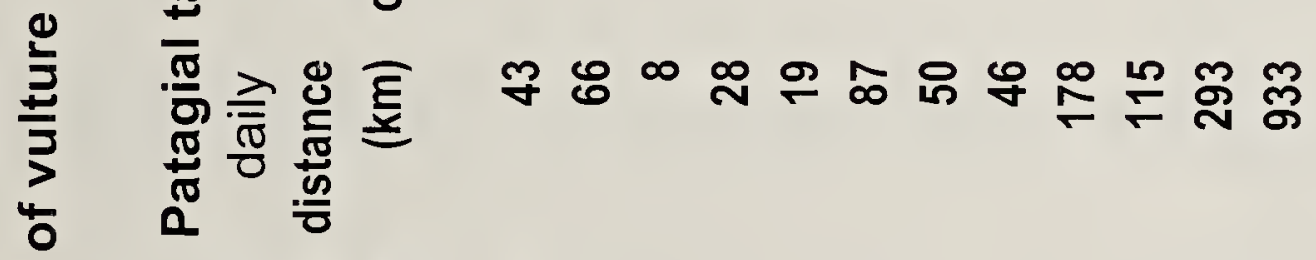

ฏ

宓

묻

늉 혼 은

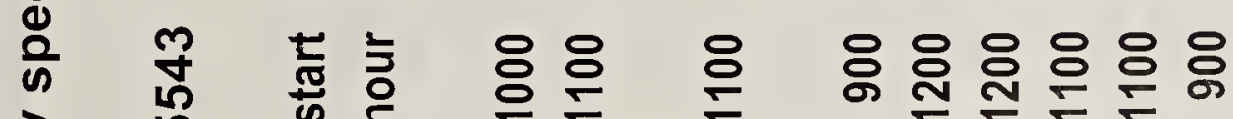

규

穴

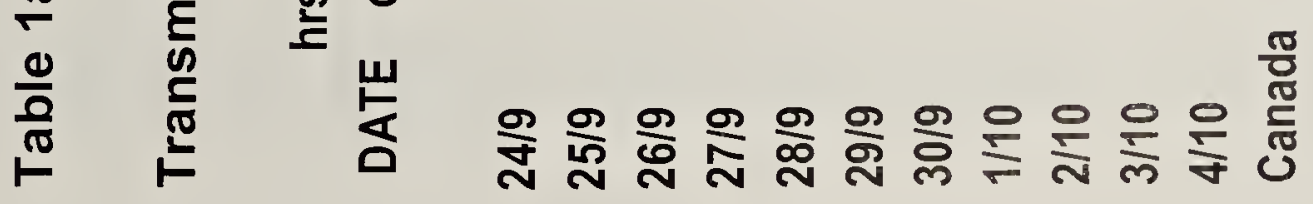




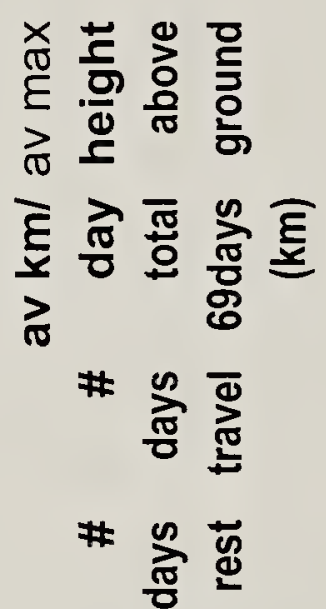

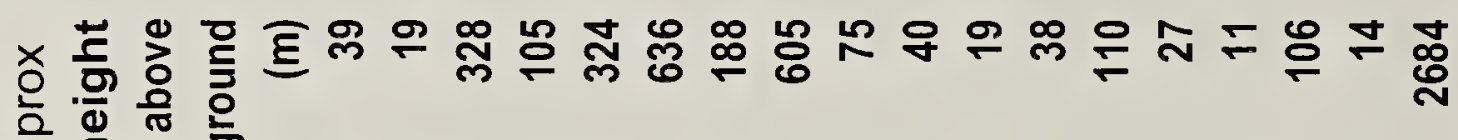
응 $\frac{2}{5}$

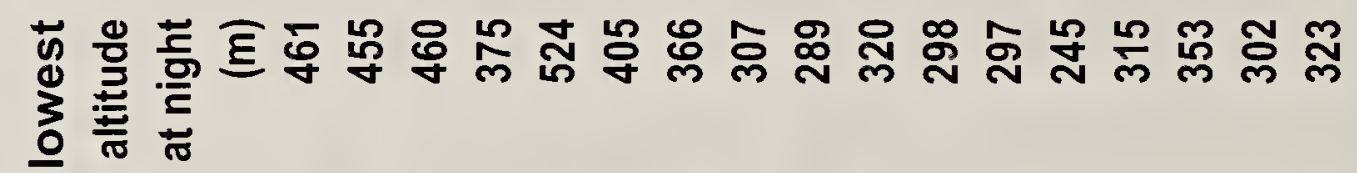

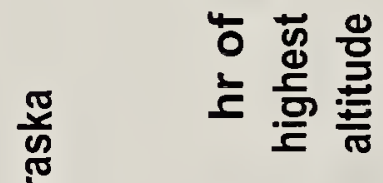

융

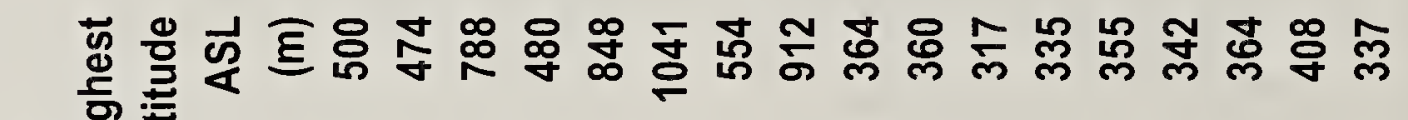
을

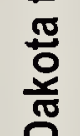

등

去 শ 진

들 을

今。

$\pm$

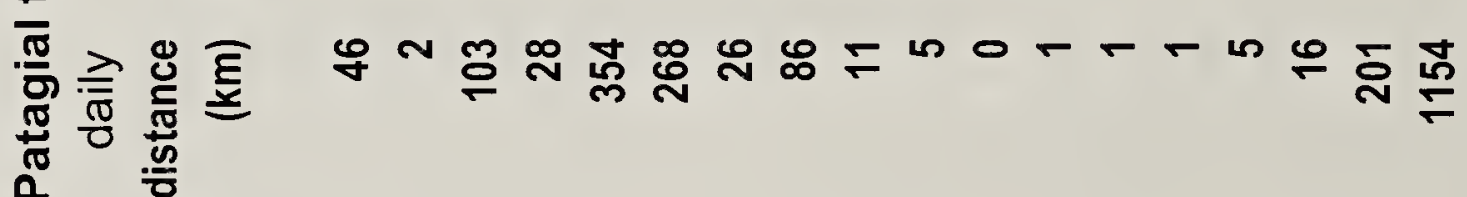

m

禹

$m \stackrel{m}{m}$ 은

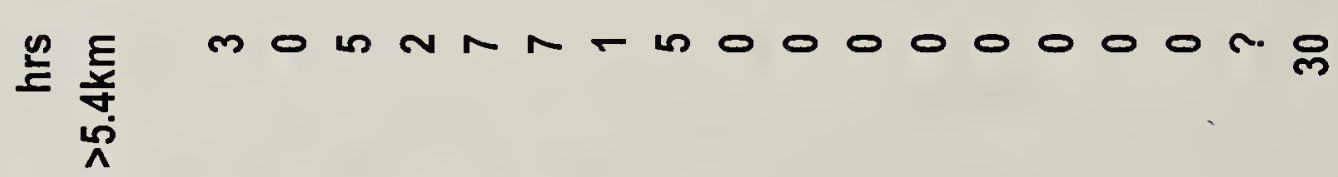

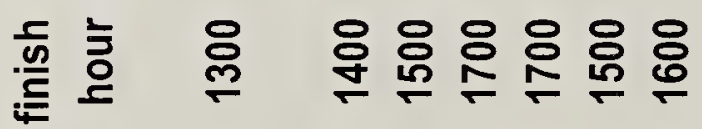

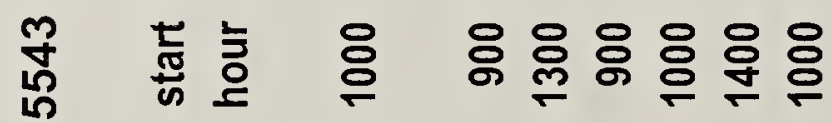




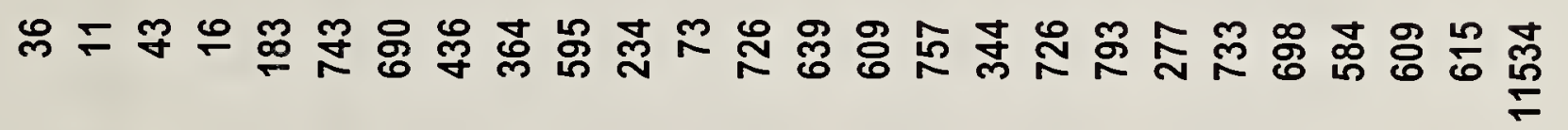

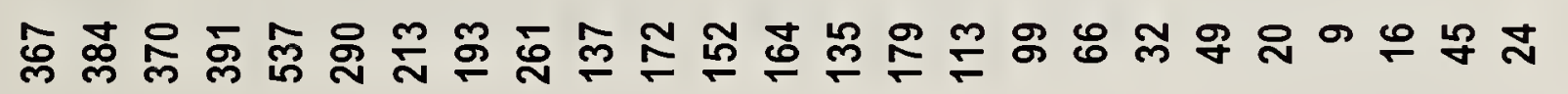

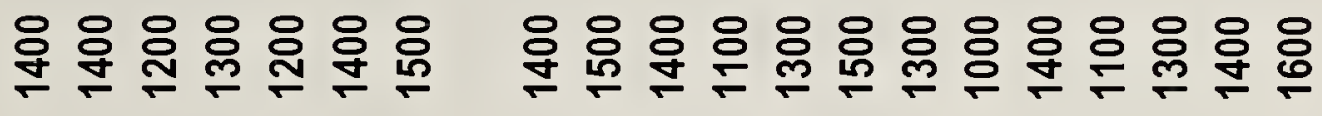

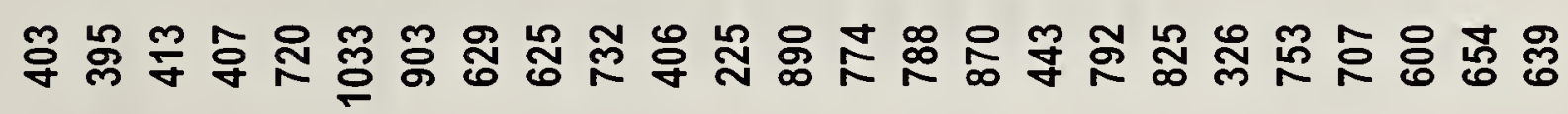

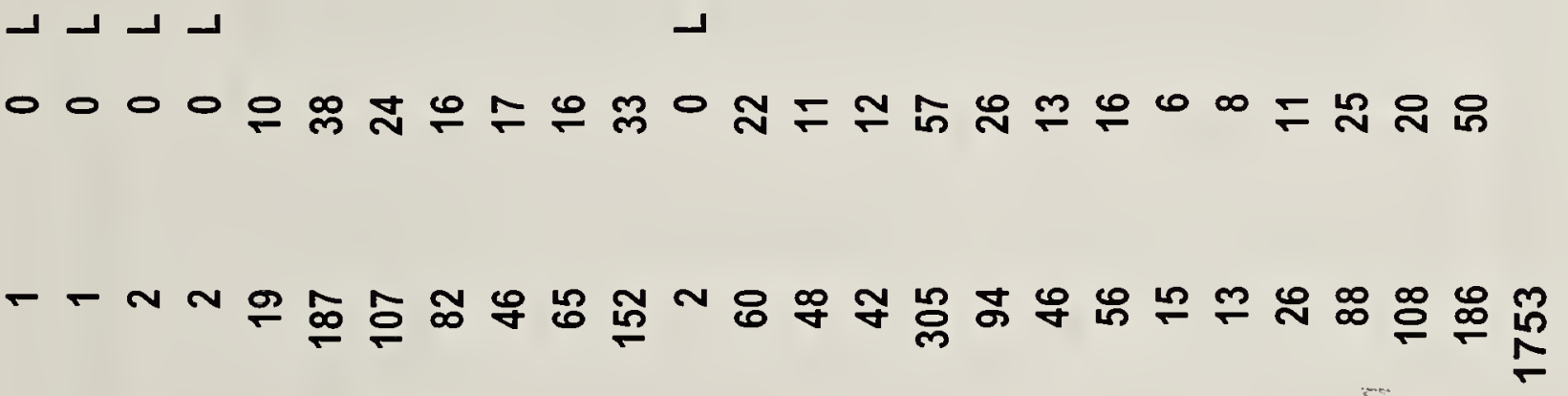

$$
\begin{aligned}
& \text { N } \rightarrow
\end{aligned}
$$

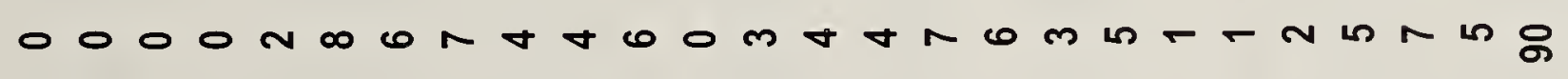

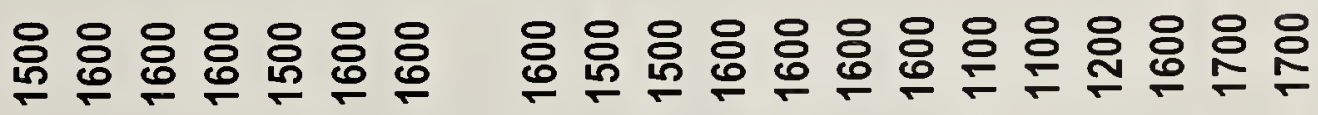

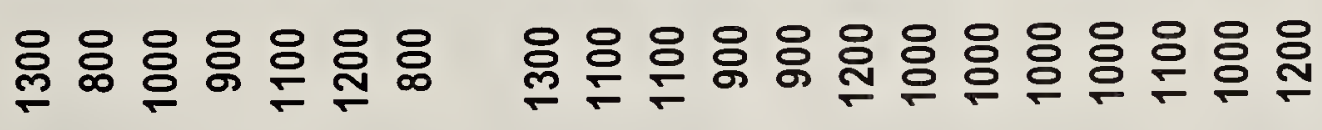
을

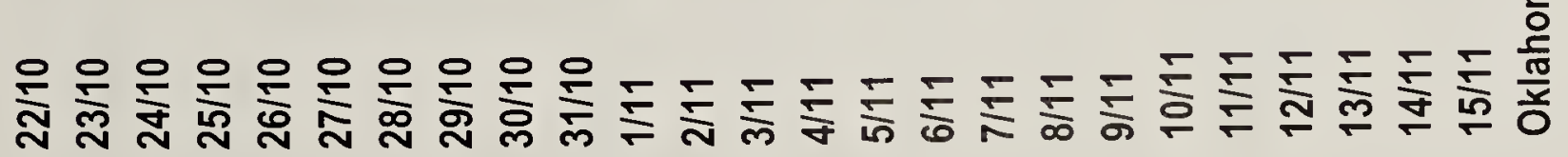




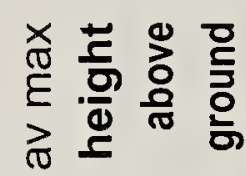

@̊

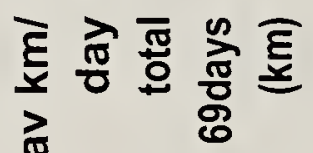

* 忞

* 帘

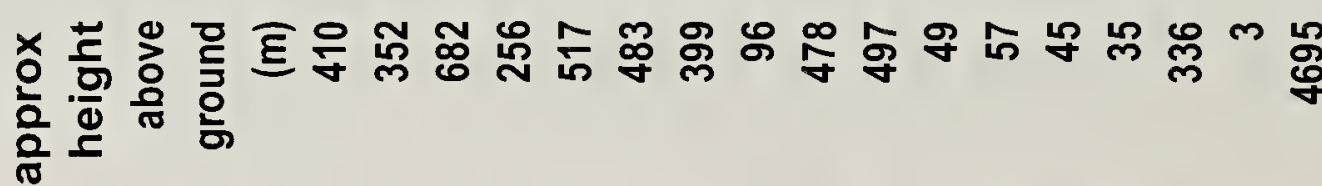

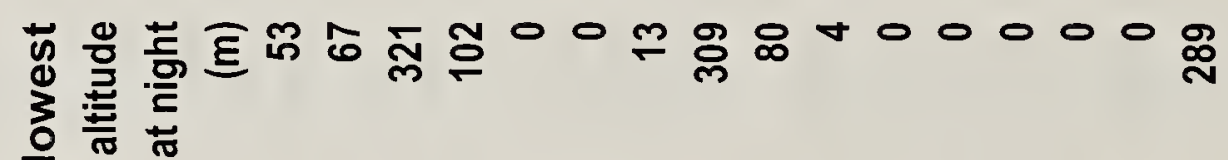

$$
\begin{aligned}
& \text { 응 }
\end{aligned}
$$

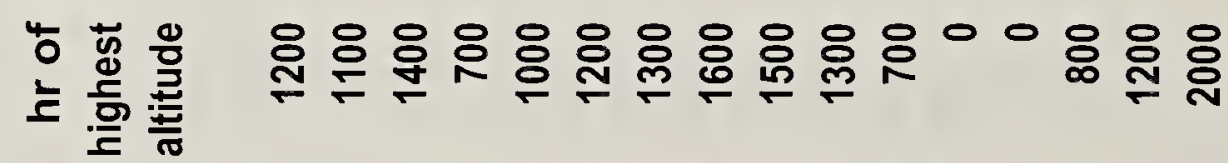

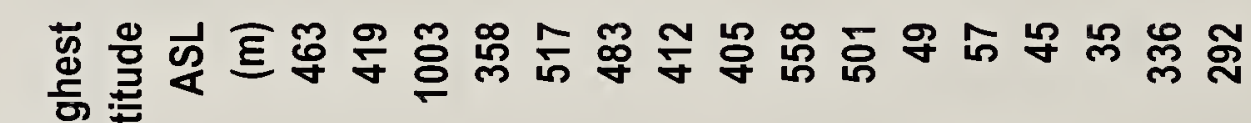

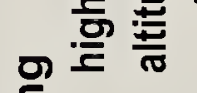

을

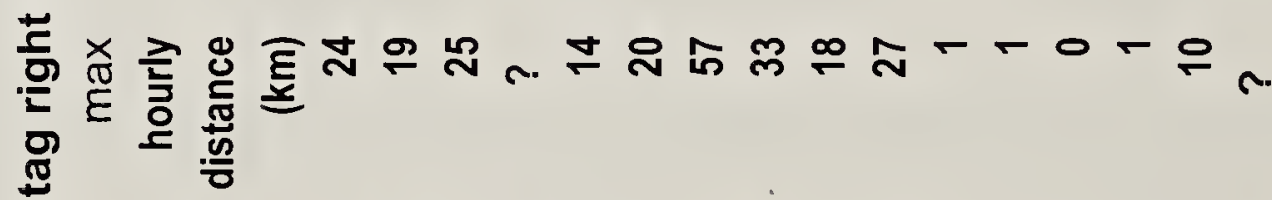

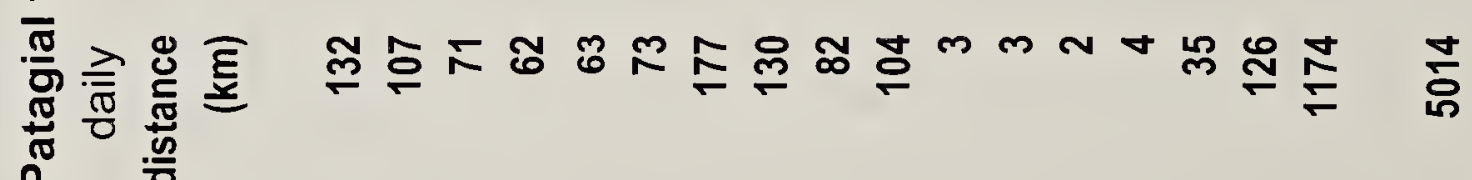
ก

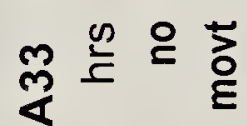

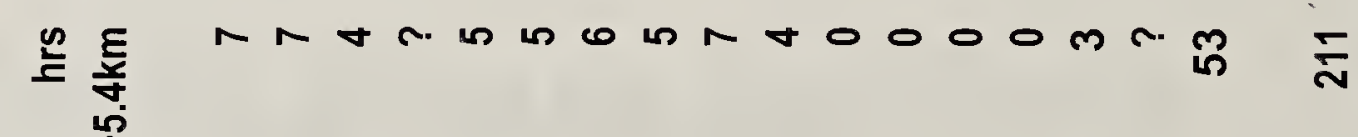

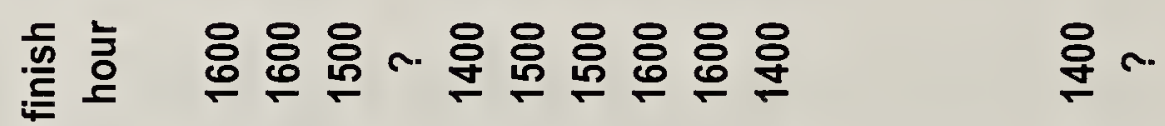

筩 壳产

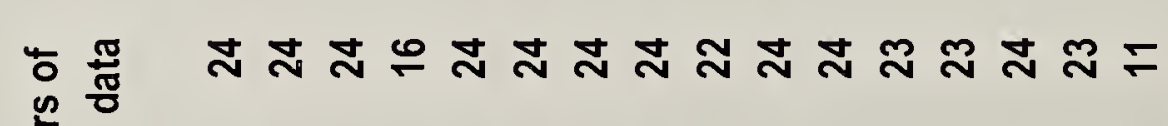
象

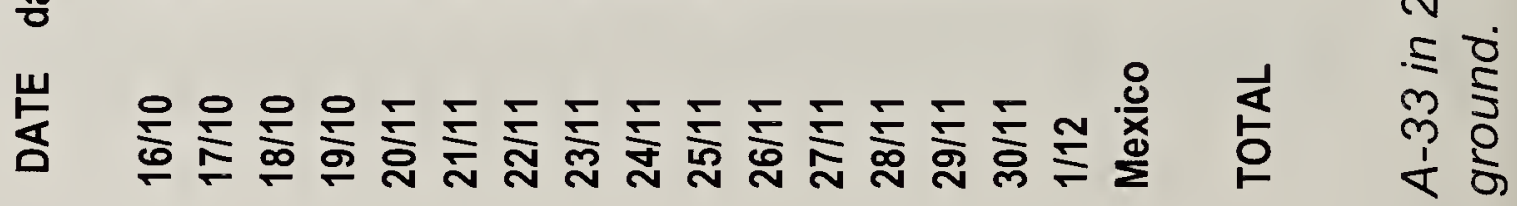




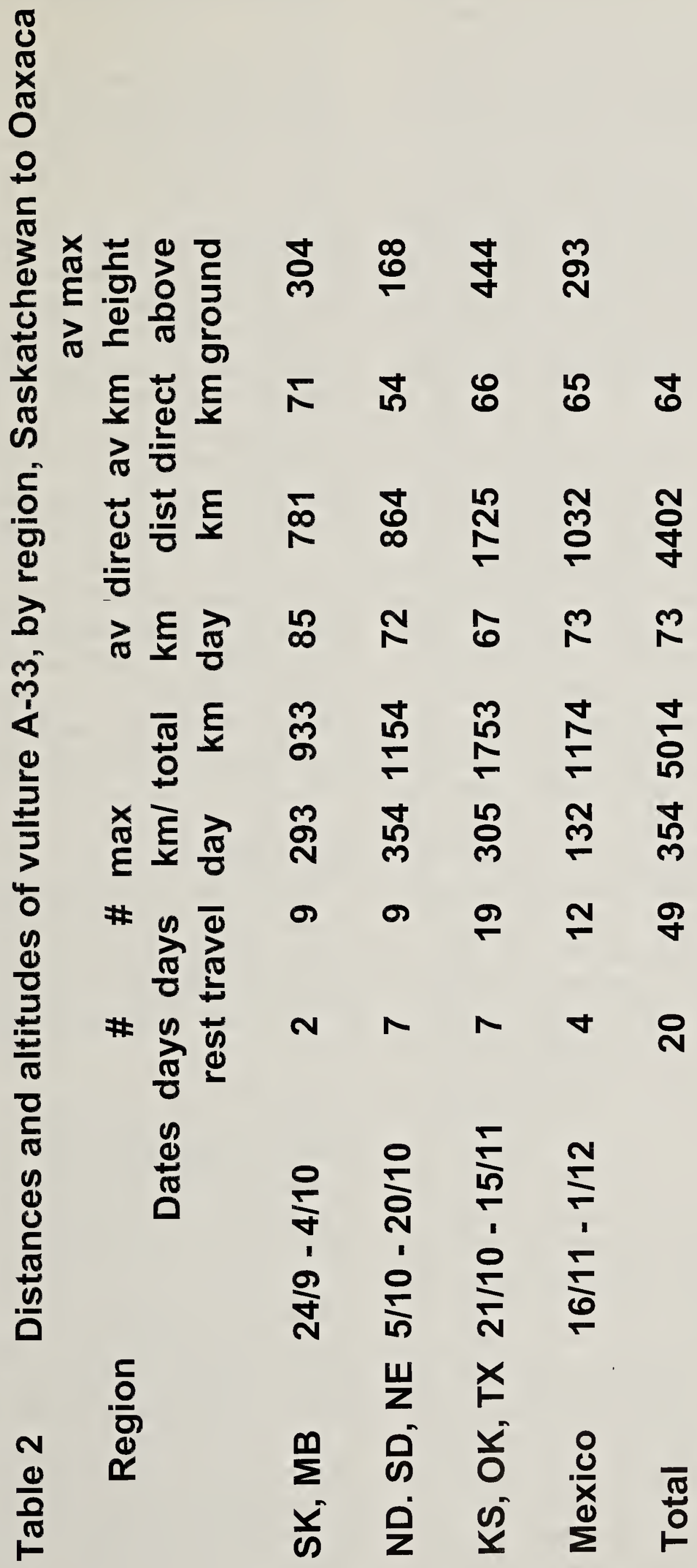


of the 1565 recorded hours clocked a speed greater than $50 \mathrm{~km} / \mathrm{hr}$, with a maximum of $67 \mathrm{~km} / \mathrm{hr}$ at $1500 \mathrm{~h}$ on October 9 . Four of these five occasions with higher speed were associated with higher than average elevations.

The highest altitude above sea level $(1395 \mathrm{~m})$ and the highest altitude above ground (936 m) occurred near Cartwright, MB on October 4. Later, the vulture traveled in near-continuous thermals along the Caribbean coast of Mexico (KLB). One might have expected it to fly at greater heights farther north, where it would soar and glide between thermals, rather than in the south where thermal streets often form and where there should be less circle soaring and inter-thermal gliding. The northerly location of the highest altitude is the only evidence that tends to support this hypothesis. However, in a further test, the mean of single daily maximum heights reached above ground, lumping both travel and rest days, was calculated: $304 \mathrm{~m}$ in Canada, $168 \mathrm{~m}$ over the Dakotas and Nebraska, $444 \mathrm{~m}$ over Kansas through Texas, and $293 \mathrm{~m}$ over Mexico (Table 2). The only "travel days" (in addition to the "rest days" with regularly low flights) that involved flights entirely below $\sim 120 \mathrm{~m}$ above ground, were four in Canada and two in North Dakota ( $\mathrm{L}$ in column 9 in Table 1). Similarly, the average distance per day, based on all 69 days, failed to show any appreciable change between the four regions: $85,72,67$ and $73 \mathrm{~km} /$ day as the vulture moved southward (Table 2).

Direct-line distances, between the first and the final readings of each period (Table 2), were shorter, at 781 $\mathrm{km}$ for Canada (mean, $71 \mathrm{~km} /$ day), 864 $\mathrm{km}$ for North Dakota to Nebraska (54 $\mathrm{km} /$ day), $1725 \mathrm{~km}$ for Kansas to Texas (66 km/day), and $1032 \mathrm{~km}$ for Mexico
(65 km/day), for a total-distance directline mean of $64 \mathrm{~km} /$ day.

An unexpected event was reported to the banding office by Bob Funke, a conservation officer/ game warden based at Fredonia, Kansas. He was called by farmer Walt Griffith, near Neosho Falls, because Griffith had observed a Red-tailed Hawk harassing a Turkey Vulture, and read its wing tag A33; the vulture then took refuge from the hawk by flying through a large open door into Griffith's machinery shed. Funke, on getting the call, rushed about $36 \mathrm{~km}$ to the Griffith farm and found the vulture hiding under a workbench. He extracted the vulture, and noticed to his surprise that the vulture also had a transmitter with antenna attached to its back. As Funke demonstrated the transmitter to the equally amazed farmer, the vulture slid out of his arms, flew out the door and went $16 \mathrm{~km}$ more before stopping for that night.

\section{Discussion}

For the first time in North America, we were able to calculate the hourly speed and altitude of a recentlyfledged Turkey Vulture during its first southbound migration. As expected for a bird using thermals, almost all the southward travel of vulture A33 occurred during midday, usually between $900 \mathrm{~h}$ and $1700 \mathrm{~h}$, during 49 'travel days.' The remaining 20 days presumably involved resting and eating, without southbound progress.

This vulture started south from the same deserted house as the 2004 vulture, $\mathrm{H} 25$. The southward migration path of A33 as far as Oaxaca (Figure 1) was almost identical to that of the 2004 vulture that wintered in Costa Rica. The 2004 vulture, H25, however, began the journey four days earlier, reached Oaxaca 22 days earlier, on 9 
November, and covered $5316 \mathrm{~km}$ in 72 days (map in Houston et al. 2007). A33 averaged $64 \mathrm{~km} /$ day using a direct-line distance from start point to end point as compared to $74 \mathrm{~km} /$ day for the direct-line distance of $\mathrm{H} 25$ in 2004.

When rest days and travel days are pooled, A33 traveled an average of 73 $\mathrm{km}$ per day for 69 days. In spite of prevailing northwesterly winds, it surpassed $50 \mathrm{~km} / \mathrm{hr}$ only five times, an hourly speed consistent with the soaring speeds of $40 \mathrm{~km} / \mathrm{hr}$ reported by Coles (a vulture keeping pace with a railway train) $)^{2}$ and the $55 \mathrm{~km} / \mathrm{hr}$ reported by Kirk and Mossman. ${ }^{7}$

Another species that most often uses soaring-gliding flight rather than powered flight during migration is the Golden Eagle. The eagle's travels resembled those of vultures in several ways. Juveniles making their first flight south from Alaska reached only a maximum of $261 \mathrm{~km} /$ day in 1997, but $472 \mathrm{~km} /$ day in 1999 , only moderately greater than the 354 and $305 \mathrm{~km}$ of the juvenile vulture's longest day's travel. The eagles also took advantage of thermals for midday travel and employed stopovers of from 2 to 19 days. $^{9}$

In contrast, raptors that use flapping flight rather than soaring-gliding flight have the potential to travel faster. A combined, pooled group of individual Saskatchewan Swainson's Hawks with leg bands, each encountered at one terminal site only, together suggest a coverage of over $10,000 \mathrm{~km}$ in 54 days, an average of $185 \mathrm{~km} / \mathrm{day}$, arriving in northern Argentina as early as November $7 . .^{10}$ An adult Saskatchewan Swainson's Hawk, fitted with a Doppler transmitter and followed every day or two for the entire journey, required 96 days to reach its wintering grounds in La Pampa province, Argentina on 30 November, a distance of $10,415 \mathrm{~km}$ in 96 days, averaging $108 \mathrm{~km} /$ day. ${ }^{4} \mathrm{An}$ adult Saskatchewan Osprey fitted with a Doppler transmitter covered a remarkable $1145 \mathrm{~km}$ in two days, from Rapid City, South Dakota to Matador Texas, and it also averaged a healthy $287 \mathrm{~km} /$ day for its 19 days of major southbound travel. ${ }^{6}$ However, the next year the same Osprey required 9 days longer to make its trip to Costa Rica (Houston 2004). ${ }^{3}$

\section{Acknowledgments}

Ralph Matzner, the landowner, and Ken McDaid, a neighbor, have kept a watchful eye on the vulture nest site near Ranger each summer since 2002. Myron Barton devoted several days to clearing underbrush to reach the GPS location of the fallen-off transmitter, 65543, which was found, on the third and final search, by Pieter Stoffel on August 2, 2006, and subsequently refurbished by Microwave Telemetery Inc. Michael J. Mossman posed important questions that have improved the value of this paper. Claude Bouchard, Professor Emeritus, Université de Laval, wrote the distance-measuring program Grinwich, adding an extra calculation to provide a daily as well as an hourly distance.

We thank Dr. Paul Howey for valuable information and assistance and for waiving the fee for Groundtrack when his company refurbished the transmitter, which thus became available for re-use in 2007. Sarkis and Bobbye Acopian supported the purchase of the PTT and other Hawk Mountain Sanctuary aspects of the project.

1. ARGOS. 2005. Argos user's manual. Online at http://www. argos-system.org/manual/

Accessed 30 June 2008 
2. COLES, V.E. 1938. Studies of the life history of the Turkey Vulture (Cathartes aura septentrionalis, Wied). Ph.D. thesis, Cornell University, Ithaca, NY.

3. HOUSTON, C.S. 2004. Osprey's second trip to Costa Rica. Blue Jay 62:214-215.

4. HOUSTON, C.S. and K.I. FUNG. 1999. Saskatchewan's first Swainson's Hawk with satellite radio. Blue Jay 57:69-72.

5. HOUSTON, C.S., G.L. HOLROYD, B. TERRY, M. BLOM, and M.J. STOFFEL. 2007. Tracking Saskatchewan nestling Turkey Vultures. Blue Jay 65:201-207.

6. HOUSTON, C.S. and M. MARTELL. 2002. Speedy migration: Saskatchewan's first Osprey satellite transmitter. Blue Jay 60:74-79.
7. KIRK, D.A., and M.J. MOSSMAN. 1998. Turkey Vulture (Cathartes aura). Birds of North America, No. 339 .

8. MICROWAVE TELEMETRY, INC. 2004. Solar PTT-100 Field Manual. Microwave Telemetry, Inc. Columbia, MD.

9. MCINTYRE, C.L., D.C. DOUGLAS, and M.W. COLLOPY. 2008. Movements of Golden Eagles (Aquila chrysaetos) from Interior Alaska during their first year of independence. Auk 125:214224.

10. SCHMUTZ, J.K., C.S. HOUSTON and G.L. HOLROYD. 1996. Southward migration of Swainson's Hawks: over $10,000 \mathrm{~km}$ in 54 days. Blue Jay 54:70-76.

\title{
EASTERN WOOD-PEWEE NEST IN SOUTHEASTERN SASKATCHEWAN
}

\author{
BOB LUTERBACH, 2109 Grant Road, Regina, SK, S4S 5C9
}

On the morning of 21 June 2008, I carefully identified a female Eastern Wood-Pewee building a nest at a former provincial picnic site in the Souris Valley along Highway \# 9. It was hovering to pick dry tops of brome grass (Bromus sp.) and then returned to integrate this material into the rim of the nearly completed nest. The nest was 'saddled' on the larger branch of a large Green Ash (Fraxinus pensylvanica) within a mature grove of Box Elder (Acer negundo) and American Elm (Ulmus americanus) with an open understory. The male called sporadically nearby.

These were two of five Eastern WoodPewees recorded that day along the route from Roche Percee to Hwy \# 9. I saw another pair interact at the former Roche Percee Provincial Recreation Site and a single bird calling $5.5 \mathrm{~km}$ to the east at Longney's Crossing.

This species is a resident in smaller numbers in the riparian areas along the Souris River including the specific area of this nest. Other general areas where I and others have observed this species include Moose Mountain Provincial Park, the eastern Qu'Appelle Valley, Good Spirit Provincial Park and Duck Mountain Provincial Park. There have also been scattered reports from several other locations.

Alan R. Smith describes the Eastern Wood-Pewee as 'a rare but regular summer resident in mature deciduous forests' mainly in the Southeastern area. ${ }^{2}$ Although it has long been accepted as a possible/probable breeding species, this is apparently the first nest record of a species that was first observed in Saskatchewan by Ernest Thompson Seton at Runnymede on 14 June $1884 .^{1}$

1. HOUSTON, C.S. 1980.(Introduction to) Ernest Thompson Seton in Manitoba 1882-1892. Manitoba Naturalist Society, Winnipeg.

2. SMITH, A. R. 1996. Atlas of Saskatchewan Birds. Special Publication \# 22. Saskatchewan Natural History Society, Regina SK. 